\title{
Kolaborasi Masyarakat Sipil dan Perusahaan dalam Pelaksanaan SDGs di Indonesia
}

\author{
Meila Riskia Fitri ${ }^{1}$ dan Putri Rima Jauhari \\ Universitas Negeri Jakarta
}

\begin{abstract}
In the history of social movements in Indonesia, civil society organisation (CSO) has taken an important role. Even since the colonial period in order to seize independence, up to this day in terms of filling the development. The global development agenda or Sustainable Development Goals (SDGs) require the role of various stakeholders, including civil society organizations and companies. The purpose of this research is to find out the form of collaboration between civil society and companies in the implementation of SDGs in Indonesia. The method used is library research. The results of this study show that Civil society Indonesia collaborates to ask the government as the person in charge of the State to implement transparent and accountable SDGs. The initiative is carried out by civil society in encouraging the role of various parties, including companies to actively participate in the implementation of SDGs in Indonesia. Among the initiatives carried out are encouraging multiparty cooperation, launching "Fiqh Zakat for SDGs", and building a multiparty platform. From the existing practices, it can be seen that there is a shifting pattern of the role of civil society, where previously faced with the State and the company, but today it is more towards collaborative work with two components in a Country.
\end{abstract}

Keywords : Social Movements, Civil Society, SDGs

\begin{abstract}
Abstrak
Dalam sejarah gerakan social di Indonesia, civil society organisation (CSO) telah mengambil peran penting. Bahkan sejak masa penjajahan dalam rangka untuk merebut kemerdekaan, sampai dengan hari ini dalam hal mengisi pembangunan. Agenda pembangunan global atau Sustainable Development Goals (SDGs) membutuhkan peran dari berbagai stakeholder, termasuk diantaranya adalah organisasi masyarakat sipil dan perusahaan. Tujuan penelitian ini yakni untuk mengetahui bentuk kolaborasi masyarakat sipil dan perusahaan dalam pelaksanaan SDGs di Indonesia. Metode yang digunakan adalah penelitian pustaka. Hasil dari penelitian ini menunjukkan bahwa Civil society Indonesia berkoalisi untuk meminta pemerintah sebagai penanggung jawab dalam Negara melaksanakan SDGs yang transparan dan akuntabel. Inisiatif dilakukan oleh masyarakat sipil dalam mendorong peran berbagai pihak, termasuk perusahaan untuk berpartisipatif aktif dalam pelaksanaan SDGs di Indonesia. Diantara inisiatif yang dilakukan adalah mendorong kerjasama multipihak, meluncurkan "Fiqh Zakat for SDGs", dan membangun platform multipihak. Dari praktik-praktik yang ada, dapat dilihat bahwa terdapat pola yang bergeser dari peran masyarakat sipil, dimana sebelumnya berhadap-hadapan dengan Negara maupun perusahaan, namun hari ini lebih kearah kerja kolaboratif dengan dua komponen dalam suatu Negara tersebut.
\end{abstract}

Kata Kunci : Gerakan Sosial, Masyarakat Sipil, SDGs

${ }^{1}$ mfitri@unj.ac.id 


\section{Pendahuluan}

Pada September 2017 lalu, pemerintah Indonesia telah mengesahkan peraturan mengenai pelaksanaan SDGs. Peraturan Presiden No. 59 Tahun 2017 ini membuktikan komitmen tinggi pemerintah terhadap pelaksanaan SDGs di Indonesia. Perusahaan merupakan salah satu aktor yang disebutkan dalam Perpres. Dengan kata lain perusahaan menjadi salah satu pilar dalam kesuksesan pelaksanaan SDGs selain pemerintah, akademisi, dan organisasi masyarakat (Ormas).

Peran multipihak dalam pelaksanaan dan pencapaian SDGs sudah pernah dibahas oleh beberapa pakar, termasuk diantaranya peran sector bisnis atau perusahan. John Ruggie ahli ilmu politik dan penulis UN Guiding principle on Bussines and Human Rights (2011) telah menulis bahwa dalam pelaksanaan dan pemajuan SDG, perusahaan tidak boleh hanya berhenti melihat SDG sebagai peluang bisnis semata, tetapi juga perlu memperhatikan dampak negative operasi mereka.

Smeru (2017) mencatat bahwa SDGs sebagai kelanjutan dari MDGs (Millenium Development Goals) memiliki perbedaan dalam perumusannya. Jika MDGs dirumuskan oleh Negaranegara OECD (Organisation for Economic Co-operation and Development) dan para pakar beberapa lembaga internasional, maka berbeda dengan SDGs yang melibatkan pemangku kepentingan yang lebih luas, baik pemerintah, masyarakat sipil, akademisi, pihak swasta, maupun filantropi, dari negara maju maupun berkembang. Perbedaan ini menjadi dasar bagi sifat partisipatoris SDGs sejak proses perumusan, pelaksanaan, sampai evaluasi.

Pentingnya peran multipihak dalam setiap proses SDGs menjadi dasar penelitian ini. Dapat dikatakan bahwa penelitian ini berusaha untuk mengumpulkan informasi mengenai peran dari salah satu aktor pembangunan penting, yakni CSO dalam mendorong keterlibatan berbagai stakeholder, termasuk perusahaan. Penelitian ini bermaksud untuk memaparkan bagaimana kerja-kerja kolaboratif yang dilakukan CSO dan Perusahaan dalam pelaksanaan SDGs di Indonesia. Dengan demikian, diharapkan dapat menjadi model pembangunan yang bisa dilakukan di berbagai daerah di Indonesia.

\section{Metode Penelitian}

Penelitian ini adalah penelitian dengan metode kajian pustaka. Pengumpulan data studi pustaka. Studi pustaka melakukaan penelusuran pustaka bukan hanya sebagai langkah awal untuk menyiapkan kerangka penelitian, dan/atau proposal untuk mendapatkan informasi tentang penelitian sejenis, memperdalam kajian teoritis, atau mempertajam metodologi, melainkan sekaligus memanfaatkan sumber pustaka untuk memperoleh data penelitian. ${ }^{2}$ Dengan demikian, informasi dan data dalam penelitian ini diambil dari sumber buku, jurnal ilmiah, hasil penelitian, artikel dan opini media elektronik yang ada di Indonesia. Sehingga kemudian bisa dianalisis dalam penelitian ini.

\footnotetext{
${ }^{2}$ Mestika Zed. Metode Penelitian Kepustakaan. Jakarta: Yayasan Obor Indonesia. 2004
} 


\section{Hasil dan Pembahasan}

\section{Peran dan Keterlibatan Perusahaan Dalam Pelaksanaan SDGs Di Indonesia}

Di Indonesia, beberapa perusahaan telah membuktikan keterlibatannya dalam pelaksanaan SDG's, dengan melakukan kampanye terkait poin-poin yang terdapat dalam SDGs dan membuat berbagai program pembangunan berkelanjutan dalam berbagai sektor. Diantara beberapa perusahaan di Indonesia yang telah bersama-sama berkomitmen dalam melaksanakan SDGs tergabung dalam Indonesia Business Council for Sustainable Development (IBCSD). Organisasi ini dapat dilihat sebagai bentuk kerja sama antar beberapa perusahaan dalam berperan aktif mewujudkan SDGs.

Terkait sektor pendidikan yang merupakan tujuan 4 SDGs mengharapkan bukan hanya semua anak mendapatkan akses pendidikan yang sama, tetapi juga diharapkan para remaja dan orang dewasa di 10 tahun yang akan datang memiliki keahlian yang relevan agar mendapatkan pekerjaan yang layak dan bisa berwirausaha. Selain itu juga diharapkan para perusahaan diharapkan ikut berpartisipasi dalam memastikan mutu fasilitas yang sensitif terhadap gender, anak, dan disabilitas, memperbanyak beasiswa untuk negara-negara berkembang dan kurang berkembang, dan meningkatkan penyediaan guru-guru yang berkualitas. ${ }^{3}$ Hal ini lah yang menjadi salah satu pertimbangan mengapa sektor pendidikan menjadi penting dan harus diprioritaskan, yakni karena bisa memengaruhi kehidupan pada masa yang akan datang.

Salah satu program yang berfokus pada peningkatan pendidikan yang berkualitas adalah program Sekolah Rakyat Ancol yang dilakukan oleh PT Pembangunan Jaya Ancol Tbk. Program ini adalah program yang berusaha untuk menyediakan pendidikan berkualitas dan layak bagi orang-orang yang kurang beruntung. ${ }^{4}$ Program ini berlokasi di Kelurahan Ancol Pademangan, Jakarta Utara dengan 113 siswa yang berada di jenjang Sekolah Menengah Pertama (SMP). Sekolah Rakyat Ancol berusaha memberikan peluang kepada anak-anak untuk mengembangkan kemampuannya. Tidak hanya di bidang akademi, tetapi mereka juga diajarkan untuk berwirausaha dengan mengelola kantin. Mereka juga belajar menari, bermain musik, public speaking, dan berwiraswasta.

Hasilnya, pada akhir 2017 berdasarkan perhidungan Social Return on Investment (SROI), program Sekolah Rakyat Ancol memberikan dampak positif dengan rasio SROI sebanyak $1: 2,90$. Dimana hasil rasio ini menujukan bahwa setiap Rp 1,00 yang di investasikan oleh perusahaan, dapat memberikan Rp 2,90 pengembalian sosial. Berdasarkan perhitungan tersebut, dapat dikatakan bahwa program Sekolah Rakyat Ancol memberikan manfaat bagi orang tua dengan mendapatkan dukungan finansial dan mengenal lebih baik tentang potensi anak-anaknya. Selain itu, para orang tua pun mendapatkan ilmu tentang kewirausahaan dan parenting. ${ }^{5}$

\footnotetext{
${ }^{3}$ Dikutip dari https://www.sdg2030indonesia.org/page/12-tujuan-empat yang diakses pada 29/10/20

${ }^{4}$ Ibid, hlm 40

${ }^{5}$ Ibid, hlm 40
} 
Sementara dalam mendukung pertumbuhan ekonomi yang inklusif dan berkelanjutan, diperlukan pemeliharaan pertumbuhan ekonomi perkapita, pencapaian level lebih tinggi untuk produktivitas ekonomi melalui sertifikasi, mendorong kebijakan berorientasi pembangunan yang mendukung ativitas produktif, penciptaan lapangan kerja, kewirausahaan, kreativitas dan inovasi da mendorong pertumbuhan usaha mikto dan menengah. ${ }^{6}$

Terkait dengan tujuan 8 SDG's adalah program "Reuse of Plastic Strapping Waste" oleh PT Indah Kiat Pulp \& Paper Tbk (Perawang Mill) - APP Sinar Mas). Melalui program ini berton-ton sampah plastic strapping telah diubah menjadi produk kerajinan, seperti keranjang, pot bunga, keset, tas, dan sebagainya. Melalui program ini juga, banyak dari anggota masyarakat Riau yang terberdayakan dan menambah penghasilan mereka mencapai Rp 800.000 hingga $\mathrm{Rp} 1.500 .00$ perbulan. Dengan anggota kelompok di awal sebanyak 3 wanita, kini menjadi 95 anggota dengan komposisi 90 wanita dan 5 pria. Selain meningkatkan penghasilan, kegiatan ini juga berdampak positif bagi linkungan dengan menerapkan prinsip 3R (Reduce, Reuse, dan Recycle).

Hal lain yang dilakukan perusahaan adalah sebagai salah satu program untuk menghadirkan kesetaraan gender di sektor ekonomi adalah "Cocoa Life - Empowering The Men, Women and Youth within Cocoa Communities to Lead Their Own Development" yang dibentuk oleh PT Mondelēz Indonesia. Program ini dilaksanakan di berbagai daerah, seperti Lampung, Sumatra Barat, Sulawesi selatan, dan Sulawesi Tenggara. Program ini berusaha untuk mendukung pemberdayaan perempuan yang menjadi salah satu prinsip Cocoa Life Program. Bekerjasama dengan Save the Children, Wahana Visi Indonesia, Swisscontact, Barry Callebaut, Cargil, dan Departemen Pemberdayaan Perempuan dan Perlindungan Anak, mereka meningkatkan kapasitas para perempuan dalam kepemimpinan, berbicara di depan umum, fasilitasi, negosiasi dan menyampaikan pendapat dalam rapat umum, memulai rencana aksi komunitas di Musrembang, Literasi Keuangan, VSLA, dan pengelolaan ekonomi rumah tangga.

Hasilnya, di akhir tahun 2018, terdapat peningkatan kapasitas lebih dari 26.000 perempuan di komunitas Cocoa. Program ini juga melatih lebih dari 5.700 anggota komunitas pada masalah kesetaraan gender yang terjadi di Indonesia. Lebih dari 30\% perempuan berpartisipasi dalam pengambilan keputusan desa (Musrenbang), lebih dari 790 wanita dalam posisi kepemimpinan, 695 kelompok VSLA dengan total tabungan banyak Rp 8,3 Milyar, 241 komunitas/kepala desa berfokus pada program pemberdayaan perempuan, 115 kelompok kecil petani wanita, 340 relawan penyuluh wanita. ${ }^{7}$

\section{Dorongan Masyarakat Sipil bagi Perusahaan}

Masyarakat Sipil seringkali dipadankan dengan konsep civil society. Keberadaan civil society di Indonesia sudah dimulai sejak lama, bahkan sejak masa pra-kemerdekaan. Secara historis, civil

\footnotetext{
${ }^{6}$ Dikutip dari https://www.sdg2030indonesia.org/page/16-tujuan-delapan yang diakses pada 29/10/20

${ }^{7}$ Ibid, hlm 50
} 
society sebagai konsep memliki akar dari proses sejarah Barat ${ }^{8}$. Civil society merupakan konsep lama yang berkembang sekitar abad ke-18. Pemikir pada saat itu merujuk kepada civil society sebagai kelompok atau kekuatan yang bebas dan mandiri dihadapkan dengan negara (the state). Kemudian konsep ini berkembang menjadi ketidakpuasan terhadap negara yang dianggap kekuasaan atau otoritasnya makin atau terlalu besar. Selain kepada Negara, ketidakpuasan juga ditujukan kepada pelaku bisnis atau pasar yang kemudian dianggap semakin tidak proporsional dengan kekuasaan ekonominya.

Civil Society menurut Larry Diamond (Rethinking Civil Society : Toward Democratic Consolidation), dipahami sebagai bidang kehidupan sosial yang terorganisir yang bersifat sukarela, menghasilkan diri, sebagian besar otonom atau mandiri dari entitas negara serta terikat tatanan hukum atau seperangkat aturan bersama. ${ }^{9}$ Namun, kemandirian civil society tidak menjadikannya tertutup dari kerja-kerja kolaboratif, seperti yang dilakukan dalam pelaksanaan Agenda Pembangunan 2030 ini. Cohen dan Arato menjelaskan bahwa civil society sering pula dipahami sebagai pihak ketiga, diantara negara dan pasar. Hal ini sejalan dengan yang dipaparkan pada bagian sebelumnya mengenai tiga komponen dalam negara yang masing-masing memiliki perannya sendiri.

"Civil society is typically defined as the un-coerced middle space or 'third sector', between state and market, an organisational characteristic of wider society and its engagement with political authority and markets. A standard definition is as: a sphere of social interaction between economy and the state, composed above all of the intimate sphere (especially the family), the sphere of associations (especially voluntary associations), social movements, and forms of public communication." (Cohen and Arato 1994: ix)

World Bank sebagai salah satu actor penting dalam pembangunan di dunia menjelaskan bahwa civil society memiliki cerita sukses dalam siklus tata kelola, yakni menggali komitmen kuat berbagai actor pembangunan untuk melakukan transparansi sampai menuntut akuntabilitas dalam setiap proses.

“The World Bank's recent World Development Report on 'Governance and the Law' assigned civil society action a specific role in the chain of governance 'from transparency to accountability', noting civil society successes in extracting greater commitment to transparency from states and market actors, publicising failures, violations and abuses, and in demanding (if not necessarily enforcing) accountability" (World Bank 2017).

Civil society di Indonesia melakukannya dengan berkoalisi untuk meminta pemerintah sebagai penanggung jawab dalam negara melaksanakan SDGs yang transparan dan akuntabel. Oleh karenanya koalisi masyarakat sipil Indonesia untuk SDGs, yang terdiri dari berbagai kelompok masyarakat sipil, bekerja sama dengan berbagai sektor, termasuk sektor swasta dalam rangka upaya mencapai SDGs di tahun 2030 .

\section{Infid; Mendorong kerjasama multipihak}

\footnotetext{
${ }^{8}$ Suharno. Telaah Kritis terhadap Masyarakat Madani (Civil Society). 2007. Dalam Jurnal Civics, Vol. 4, No. 2 , Desember 2007

${ }^{9}$ Gili Argenti. CIVIL SOCIETY, SHADOW STATE DAN LOCAL STRONGMEN DALAM KAJIAN POLITIK

LOKAL. 2018. Dalam Cosmogov: Jurnal Ilmu Pemerintahan Vol.4, No.1, April 2018
} 
Sebagai salah satu NGO yang cukup senior di Indonesia, Infid mengambil peranan cukup penting dalam pelaksanaan SDGs di Indonesia. Dimulai sejak persiapan SDGs disepakati, atau dikenal dengan masa Post-2015 Development Agenda, Infid bersama dengan organisasi masyarakat sipil lain mendorong tata kelola pelaksanaan SDGs yang transparan, akuntabel, dan partisipatif.

Agenda Pembangunan 2030 atau SDGs yang disepakati pada tahun 2015 merupakan kelanjutan dari agenda pembangunan MDGs. Pada pelaksanaan MDGs, Indonesia terbilang masih memiliki catatan kritis, mulai dari perihal tata kelola sampai dengan pencapaian tiap tujuannya. Pada saat MDGs, Indonesia baru mengeluarkan dasar hukum berupa Inpres No.3 Tahun 2010 tentang Program Pembangunan yang berkeadilan. Artinya terdapat keterlambatan paling tidak 10 tahun sejak MDGs disepakati oleh Negara-negara anggota PBB, termasuk Indonesia.

Kesalahan ini diharapkan tidak lagi terjadi pada masa SDGs, oleh karenanya masyarakat sipil mendorong agar dasar hukum pelaksanaan SDGs diselesaikan sejak awal. Kemudian terbitlah Perpres 59/2017. Dalam peraturan ini termuat pula keterlibatan multipihak dalam pelaksanaan SDGs di Indonesia. Usulan tentang hal ini sudah dilakukan sejak SDGs disepakati.

Perpres No. 59 Tahun 2017 Pasal 8 menyebutkan bahwa Tim Koordinasi Nasional yang terdiri atas Dewan Pengarah, Tim Pelaksana, Kelompok Kerja, dan Tim Pakar. Lebih lanjut lagi, keterlibatan multi pihak termuat dalam Tim Pelaksana yang dimaksud dalam Pasal 10 bahwa anggota tim pelaksana terdiri dari unsur kementerian/lembaga, filantropi, dan pelaku usaha, akademisi, dan ormas.

Sejalan dengan hal tersebut, Infid mereplikasi pola tim koordinasi nasional, yang merupakan usulan dari koalisi masyarakat sipil, pada level daerah. Sampai dengan tahun 2017, setidaknya 6 Kota/Kabupaten sudah siap untuk membentuk Tim Koordinasi. Diantara Kota/Kabupaten yang dimaksud adalah Kab. Jember, Kab. Maros, Kota Banda Aceh, Kota Kupang, dan Prov. DI Yogyakarta. Komitmen berbagai pihak termasuk perusahaan ditunjukkan dengan keterlibatan aktif dalam tim koordinasi yang dimaksud.

\section{BAZNAS; Meluncurkan "Fiqh Zakat for SDGs"}

Pada akhir Juli 2018 lalu, Baznas meluncurkan Buku Fikih on SDGs. Buku ini diharapkan dapat menjadi contoh baik tentang pengelolaan zakat. Kajian yang dirilis oleh Baznas dengan judul Sebuah Kajian Zakat untuk SDGs menekankan bahwa zakat merupakan salah satu instrumen keuangan sosial Islam yang bertujuan untuk memenuhi bahkan meningkatkan Maqashid Syariah individu. Maqashid Syariah yang dimaksud sejalan dengan SDGs yang memiliki prinsip tanpa kemiskinan, kesehatan yang baik, dan tanpa kelaparan. Dengan demikian terdapat hubungan yang relevan antara maqashid syariah sebagai kerangka tujuan Zakat dan SDGs. Meski demikian relevansi yang terjadi merupakan kesesuaian berdasarkan konteks kebutuhan dari kondisi mustahik.

Relevansi dari kajian tersebut dengan realisasi yang dilakukan Baznas yakni dengan bekerjasama dengan berbagai pihak untuk mendapatkan dukungan. Salah satu langkah yang ditempuh Baznas sesuai kajian tersebut yakni dengan mengelola dana CSR untuk pengentasan kemiskinan. Hal 
ini karena penyaluran zakat memiliki irisan yang besar dengan pencapiaan SDGs. Misal yang dilakukan oleh PT. Ufia Tirta Mulia yang memiliki bidang usaha pada air minum kemasan mempercayakan penyaluran infak kepada Baznas pada tahun 2018, dimana pada tahun sebelumnya mereka mempercayakan dana CSR untuk dikelola oleh Baznas.

\section{Oxfam di Indonesia; Platform multipihak Track-SDGs}

Oxfam adalah organisasi nirlaba dari Inggris yang berfokus pada pembangunan penanggul PT. Ufia Tirta Muliangan bencana dan advokasi, bekerja sama dengan mitra lainnya untuk mengurangi penderitaan di seluruh dunia. Organisasi ini terdiri dari 15 organisasi dari 98 negara di dunia. Didirikan pada tahun 1942 di Oxford.

Dalam rangka mendukung agenda pembangunan di Indonesia, Oxfam melakukan kerja kolaborasi bersama dengan organisasi masyarakat lain. Misal dalam membangun platform online Track SDGs di mana bekerja sama dengan CISDI. TrackSDGs.id merupakan kanal bagi aktor pembangunan yang ingin menyebarluaskan capaian dan praktik baik yang didapatkan selama menjalankan program-program pembangunan yang berkontribusi terhadap pencapaian Sustainable Development Goals (SDGs) di Indonesia.

Melalui platform ini, aktor pembangunan di seluruh Indonesia dapat berjejaring dan berkolaborasi dengan mitra pembangunan lain yang memiliki visi dan misi yang sama. Platform ini bertujuan untuk mendorong terbentuknya mekanisme pemantauan implementasi SDGs yang dapat secara efektif meningkatkan kualitas, transparansi, dan akuntabilitas setiap pelaku pembangunan.

Inisiatif tersebut diantaranya dilakukan oleh masyarakat sipil dalam mendorong peran perusahaan untuk berpartisipatif aktif dalam pelaksanaan SDGs di Indonesia. Dari praktik tersebut, dapat dilihat bahwa terdapat pola yang bergeser dari peran masyarakat sipil, dimana sebelumnya berhadap-hadapan dengan negara maupun perusahaan, namun hari ini lebih kearah kerja kolaboratif dengan dua komponen dalam suatu negara tersebut.

\section{Kesimpulan}

Keterlibatan perusahaan memiliki peran penting dalam menyukseskan pelaksanaan SDGs. Sampai saat ini, sudah terdapat beberapa perusahaan di Indonesia telah berkontribusi dalam menyukseskan pelaksanaan SDGs, termasuk dalam sektor pendidikan, ekonomi, dan kesetaraan gender. Selain itu, untuk mempertahankan komitmen perusahaan dalam melaksanakan SDGs ini, perlu adanya peranan civil society dalam mendorong terbentuknya mekanisme pemantauan implementasi SDGs yang dapat secara efektif meningkatkan kualitas, transparansi, dan akuntabilitas setiap pelaku pembangunan. Seperti mendorong pembentukan tim koordinasi yang melibatkan multipihak, menyelaraskan SDGs dengan keagamaan, serta membuat platform digital sehingga semua pihak dapat memantau kerja kolaboratif dalam pelaksanaan SDGs di Indonesia. 


\section{Daftar Pustaka}

Agarwal, Namit, \& dkk. (2017). Raising the bar. London: Oxfam.

Argenti, G. (2018, April 1). Civil Society, Shadow State dan Local Strongmen Dalam Kajian Politik Lokal. Cosmogov : Jurnal Ilmu Pemerintahan, Vol 4, No 1.

Indonesia Business Council for Sustainable Development (IBCSD). (2019). Private Sector Contribution to Achieve SDGs in Indonesia. Jakarta: IBCSD.

Panuluh, S., \& Fitri, M. R. (2016). Perkembangan Pelaksanaan Sustainable Development Goals. Jakarta: INFID.

Perkasa, A. (2015, November 23). PEMBANGUNAN BERKELANJUTAN: Masyarakat Sipil Minta Pembentukan Panitia Bersama. Retrieved Oktober 31, 2020, from Bisnis.com: https://ekonomi.bisnis.com/read/20151223/9/504468/pembangunan-berkelanjutanmasyarakat-sipil-minta-pembentukan-panitia-bersama

Suharno. (2007, Desember 2007). Telaah Kritis Terhadap Masyarakat Madani (Civil Society). Civics, Vol 4, No 2.

Track SDGs. (n.d.). Retrieved Oktober 30, 2020, from Track SDGs: https://www.tracksdgs.id/

Zed, Mestika. (2004). Metode Penelitian Kepustakaan. Jakarta: Yayasan Obor Indonesia 